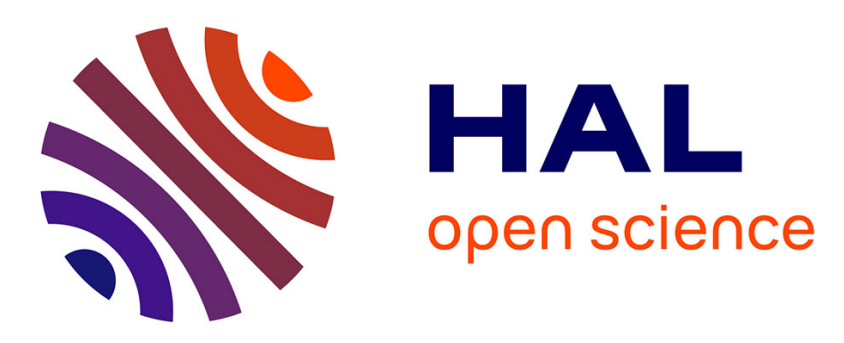

\title{
Determination of the bond strength of treated wood strands embedded in a cement matrix by means of a pull-out test
}

Stephan Frybort, Raimund Mauritz, Alfred Teischinger, Ulrich Müller

\section{To cite this version:}

Stephan Frybort, Raimund Mauritz, Alfred Teischinger, Ulrich Müller. Determination of the bond strength of treated wood strands embedded in a cement matrix by means of a pull-out test. European Journal of Wood and Wood Products, 2009, 68 (4), pp.407-414. 10.1007/s00107-009-0383-4 . hal00568258

\section{HAL Id: hal-00568258 \\ https://hal.science/hal-00568258}

Submitted on 23 Feb 2011

HAL is a multi-disciplinary open access archive for the deposit and dissemination of scientific research documents, whether they are published or not. The documents may come from teaching and research institutions in France or abroad, or from public or private research centers.
L'archive ouverte pluridisciplinaire HAL, est destinée au dépôt et à la diffusion de documents scientifiques de niveau recherche, publiés ou non, émanant des établissements d'enseignement et de recherche français ou étrangers, des laboratoires publics ou privés. 


\section{焦 Springer}

Draft Manuscript for Review

\section{Determination of the bond strength of treated wood strands embedded in a cement matrix by means of a pull-out test}

\begin{tabular}{|r|l|}
\hline Journal: & Holz als Roh- und Werkstoff \\
\hline Manuscript ID: & HRW-09-0012.R1 \\
\hline Manuscript Type: & ORIGINALARBEITEN / ORIGINALS \\
\hline Author: & 27-May-2009 \\
\hline & $\begin{array}{l}\text { Complete List of Authors: } \\
\text { Teischinger, Alfred; BOKU Vienna, Department of Material Sciences } \\
\text { and Process Engineering, Institute of Wood Science and Technology } \\
\text { Müller, Ulrich; Wood K plus }\end{array}$ \\
\hline Keywords: & $\begin{array}{l}\text { cement bonded, wood strand, pull-out test, moisture content, } \\
\text { chemical treatment, accelerator, extraction }\end{array}$ \\
\hline
\end{tabular}

\section{ScholarONE" \\ Manuscript Central}




\title{
Determination of the bond strength of treated wood strands embedded in a cement matrix by means of a pull-out test
}

\author{
Frybort, S., Mauritz, R., Teischinger, A., Müller, U. \\ Wood K plus - Competence Centre for Wood Composites and Wood Chemistry, \\ Linz Austria, Peter-Jordan-Strasse 82, 1190 Vienna, Austria \\ s.frybort@kplus-wood.at
}

\begin{abstract}
Effects of chemical treatment of wood on the bonding strength of Norway spruce strands (Picea abies Karst.) embedded in a cement matrix were investigated by means of a pull-out test. Strands of varying thickness were used whereas a strong influence of thickness on bonding strength could be observed. Using thick strands $(800 \mu \mathrm{m})$ showed negative effect on bonding strength which is due to the swelling effect. The treatment of thin strands $(400 \mu \mathrm{m})$ showed that using wet strands ( $\sim 90 \%$ moisture content) leads to the best results compared to untreated dry (12\%) strands. By addition of setting accelerators (ammonium chloride) bonding strength of wet strands was even improved. Furthermore, effects of hot water and sodium hydroxide extraction as well as sodium silicate treatment were examined.
\end{abstract}

\section{Zusammenfassung}

Zur Bestimmung der Bindefestigkeit zwischen Holz und Zement wurden anhand von unterschiedlich behandelten Strands aus Fichtenholz (Picea abies Karst.) Auszugstests durchgeführt. Strands mit unterschiedlicher Dicke wurden in die Zementmatrix eingebettet, wobei ein starker Einfluss der Stranddicke auf die Bindefestigkeit nachgewiesen werden konnte. Die Verwendung dicker Strands $(800 \mu \mathrm{m})$ zeigte einen negativen Einfluss auf die Bindefestigkeit, welcher auf

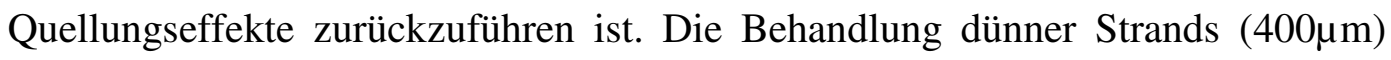
ergab, dass die Verwendung feuchter Strands $(\mathrm{u} \sim 90 \%) \mathrm{zu}$ den besten Ergebnissen führte. Bei einer zusätzlichen Verwendung eines 
Erstarrungsbeschleunigers (Ammoniumchlorid) konnte die Bindefestigkeit weiter verbessert werden. Ferner wurden die Effekte von Heißwasser- und Natronlaugeextraktion sowie die Behandlung mit Natronwasserglas untersucht. 
The popularity of cement bonded composites ( $\mathrm{CBCs})$ is rising throughout the industry due to its extended applications compared to conventional Engineered Wood Products (Eusebio 2003). Waste wood and low quality wood resources (e.g., wood from plantations) can be used for the production of CBCs. CBCs are widely used in Third World Countries which is partly caused by the insufficient supply of wood resources for housing and load bearing constructions. Due to the increasing use of thinnings, plantation wood, and waste wood, CBCs are getting more important even in countries with highly established wood industry. Beside economical also environmental reasons force the development of natural fibre or particle reinforced CBCs. To enable the use of CBCs also for structural purposes, bonding between wood and cement must be improved. Hence it is important to understand the bonding mechanisms between wood and cement.

Similar to adhesive bonding by means of synthetic resins also inorganic adhesion is thought to result from physical bonding mechanisms as well as mechanical interlocking (Frybort et al. 2008). Unexpected high bonding strength can be observed between wood and cement, which Wei et al. (2004) related to the hydration products (calcium hydroxide and calcium silicate hydrates), accumulating close to the wood-cement interface.

In comparison to matrix materials without reinforcement, composites with a reinforcing phase show better mechanical performance partly caused by increased toughness. This fact enables these composites to carry load to a higher strain limit. At the proportional limit micro-cracks in the matrix phase occur. However, particles begin to efficiently carry loads and block fracture propagation (Wolfe and Gjinolli 1996). A more or less "weak" interface between the matrix and the reinforcing phase, which can be observed for cement bonded wood composites, contributes to an enhanced fracture toughness of the fibre reinforced composite materials. Frictional dissipation along the interfaces is the primary source of toughness and energy absorption. Strong interfaces lead to creep resistant and brittle composites (Evans et al. 1991). By increasing bonding and pull-out strength of the fibres or particles in CBCs, toughness is additionally increased (Lange et al. 1996). To increase toughness and strength of CBCs, enhancing bonding strength of the particles and the matrix is a priority objective. 
When concrete is stressed, small cracks arise introduced due to randomly distributed flaws. Under load these micro-cracks grow together forming macrocracks which lead to failure of the structure. Reinforcing concrete with fibres inhibits crack initiation and growth, hence increasing fracture toughness of concrete (Issa et al. 1996). Conventional test methods (Jorge et al. 2004) of inorganic bonded wood composites measure the compatibility between wood and cement by measurement of the hydration characteristics (Alberto et al. 2000; Wei et al. 2000a, b; Brandstetr et al. 2001; Karade et al. 2003), as well as testing mechanical properties of cured composites (Lee and Hong 1986; Wei et al. 2003). These methods are useful for a general estimation of the compatibility of different wood species and cement. However, conventional test methods give no information concerning the adhesive bonding and the mechanical interlocking of the cement matrix to the wood surface.

The idea of using the pull-out test is to evaluate the actual bond strength of the two components and how particular treatments enhance the load transmission between the enforcement, in this case the strands, and the matrix.

As this test setup, with a strand thickness of $400 \mu \mathrm{m}$, is based on comparatively realistic wood dimensions (Geimer et al. 1996), applicable results can be gained, concerning e.g., cement bonded wood wool board or cement bonded OSB (Oriented Strand Board). Differently treated wood samples, which are cut by a microtome, are subsequently embedded into a cylindrical cement block. After curing, pull-out strength or shear strength and shear energy is measured by means of a universal test machine.

On the one hand the application-oriented approach enables test results which are useful for further work, e.g., for finite element modelling. On the other hand the data is valuable to clearly determine the influence of different treatments or the application of several coupling agents on the wood strands.

The pull-out test in general is a quite common method to determine bond strength of fibres and cement (Banholzer et al. 2004), but almost no literature is available about measuring bond strength of cement and wood particles like strands, excelsior or flakes. As there are no comparable results, the following work describes the effects of common chemical treatments and the use of an accelerator, namely ammonium chloride $\left(\mathrm{NH}_{4} \mathrm{Cl}\right)$. Those substances were chosen because they are cited in the literature as quite common methods to enhance 
compatibility (Geimer et al. 1996; Alberto et al. 2000) but acting in different ways. While $\mathrm{NaOH}$ extracts inhibitory substances out of the wood, $\mathrm{Na}_{2} \mathrm{SiO}_{3}$ is modifying the wood surface.

The motivation of this study was to evaluate the effects of different treatments of the reinforcing wood phase on the adhesive bond. Measuring frictional forces between wood and concrete which can be observed after debonding between both phases was not part of this work.

\section{Materials and methods}

\subsection{Production of the strands and embedment into cement}

Flawless blocks of spruce (Picea abies Karst.), with the dimensions $18 \mathrm{~mm} \times 30 \mathrm{~mm} \times 120 \mathrm{~mm}$, were cut out of frozen thinning material. The blocks were cut in a way that the growth rings were perpendicular to the $120 \mathrm{~mm} \times 18 \mathrm{~mm}$ radial surface (Fig. 1a). Prior to cutting the wood blocks they were stored in water at room temperature for $24 \mathrm{~h}$. After soaking, strands with a thickness of $400 \mu \mathrm{m}$ were cut along the grain from the radial surface of each block.

Due to the high bonding strength of some treatments several strands broke before debonding occurred. For this reason an additional test run was performed where strands with a thickness of $800 \mu \mathrm{m}$ were tested. As this method also failed, strands with a thickness of $400 \mu \mathrm{m}$ were embedded less deep $(10 \mathrm{~mm})$ into the cement block, whereas strands of the first run stuck $15 \mathrm{~mm}$ deep in the cement block.

\subsection{Preliminary treatment of test specimens}

The strands of each block and treatment were randomized to prevent a systematic bias. The strands were stored and treated, respectively, depending on the particular treatment (Table 1). For $\mathrm{Na}_{2} \mathrm{SiO}_{3}$ and $\mathrm{NaOH}$ treatment the strands were immersed in the particular dilution for $1 \frac{1 / 2}{\mathrm{~h}}$ and again conditioned to a moisture content of $\omega=12 \%$. For the accelerated samples $2 \%$ of $\mathrm{NH}_{4} \mathrm{Cl}$ based on cement weight were added to the cement prior to mixing with water. The so called wet samples were stored under water for $10 \mathrm{~min}$.

To determine the actual embedment depth, small marks were drawn on each strand above and below the desired $15 \mathrm{~mm}$ and $10 \mathrm{~mm}$ embedment mark, 
respectively. Subsequently, the strands were embedded into small film containers which were filled with mixed Portland limestone cement (PZ 275 CEM II/A-L $42,5 \mathrm{~N})$ water slurry at a water-cement $(\mathrm{w} / \mathrm{c})$ ratio of 0.5 . The specimens were left $24 \mathrm{~h}$ for setting. Subsequently, for complete curing, the specimens were stored in a climate room $\left(20^{\circ} \mathrm{C}, 65 \% \mathrm{RH}\right)$ for 28 days.

\subsection{Mechanical testing}

All mechanical tests were performed on a Zwick/Roell Z020 universal testing machine equipped with a $5 \mathrm{kN}$ load cell. One end of the strands was fixed by means of a clamp (lower part of the test set-up) and the cement block was hinged in a bracket. Avoiding a bending moment during testing the bracket was attached to the machine with a cardan joint. The pull-out samples were tested to failure (Fig. 1b), which was defined as force drop of $5 \%$ from $F_{\max }$. The mechanical tests were performed at constant cross-head speed of $2 \mathrm{~mm} / \mathrm{min}$. Pull-out shear strength $(\tau)$ was calculated by dividing the maximum load by the embedded superficies surface of the strand. During the mechanical experiment a force-displacement curve was recorded by the testing machine (Fig. 2).

For the individual groups the average value as well as the standard deviation was calculated and compared by one-way ANOVA $(\mathrm{p}=0.05)$.

\section{Results}

Strands treated with $\mathrm{Na}_{2} \mathrm{SiO}_{3}$ and $\mathrm{NH}_{4} \mathrm{Cl}$ showed high bonding strength. Most of these strands which were embedded $15 \mathrm{~mm}$ in the cement block failed, before shear failure at the wood-cement interface was observed. Therefore, an additional series of pull-out tests was performed with thicker wood strands $(800 \mu \mathrm{m})$ to prevent failure of the strands. However, shrinkage of the strands during curing of the cement caused de-bonding at the wood-cement interface yielding shear strength values far below values gained from thin $(400 \mu \mathrm{m})$ strands. On the other hand, no effect of the treatment was observed for those strands (Fig. 4). Therefore, the embedding depth was reduced to $10 \mathrm{~mm}$ for a second series of pull-out tests with strands with a thickness of $400 \mu \mathrm{m}$. Values gained from strands which failed in tension were not used for statistical analysis. Shear strength values yielded from pull-out tests of strength with an embedding depth of 10 and $15 \mathrm{~mm}$ were compared by one way ANOVA proving no significant difference between groups 
with the same strand treatment. For further statistical analysis strands with the same treatment were classified in one group.

In Fig. 3, the pull-out strength is plotted against untreated and the differently treated strands which were embedded in cement with and without added accelerator $\left(\mathrm{NH}_{4} \mathrm{Cl}\right)$, respectively. For clearness mean pull-out strength values and standard deviations of the experimental results are listed in Table 2, including also the results from the previous study with an embedment depth of $15 \mathrm{~mm}$.

According to the results of a one way ANOVA by using Scheffés procedure, the effects of the different treatments on pull-out strength were generally classified into four groups based on the arrangement of the pull-out strength. Group one consisting of untreated strands $\left(0.36 \pm 0.072 \mathrm{~N} / \mathrm{mm}^{2}, \mathrm{n}=14\right)$ and $\mathrm{Na}_{2} \mathrm{SiO}_{3}$ treated strands $\left(0.47 \pm 0.079 \mathrm{~N} / \mathrm{mm}^{2}, \mathrm{n}=14\right)$, group two of $\mathrm{Na}_{2} \mathrm{SiO}_{3}$ treated strands and untreated strands which were embedded into accelerated cement $(0,57 \pm$ $0,096 \mathrm{~N} / \mathrm{mm}^{2}, \mathrm{n}=13$ ), group three of untreated strands embedded in accelerated cement and wet $(\mathrm{MC} \sim 92 \%)$ embedded strands $\left(0,59 \pm 0,103 \mathrm{~N} / \mathrm{mm}^{2}, \mathrm{n}=11\right)$ and the last group consisting of wet strands ( $\mathrm{MC} \sim 92 \%)$ embedded into accelerated cement $\left(0,73 \pm 0,076 \mathrm{~N} / \mathrm{mm}^{2}, \mathrm{n}=8\right)$. Comparing the results of the accelerated wet and the untreated $(12 \%)$ samples, pull-out strength of the former one is twice as high. As $\mathrm{NaOH}$ treatment did not lead to a significant improvement, this specific treatment was not repeated in the following studies. A similar result was measured at samples with slightly higher MC of $20 \%$; just a minimal trend of improvement of bonding strength could be observed, but not at a significant level.

\section{Discussion}

When a load is applied, measured shear stress is increasing until the shear strength of the interface is reached. At this point the strand debonds and, in most cases, is pulled out without any further increase in load. Because of the frictional forces, which are getting effective when slipping of the strand starts, the stress strain curve shows a so called saw tooth pattern (Fig. 2). In some cases frictional forces lead to a slight increase in load until complete pull-out of the strand. In this case, after debonding, the stress strain curve shows some increase which again can be followed by a saw tooth like pattern or just a decrease of the stress strain curve. For statistical analysis the peak force after the first force drop was used, which clearly indicates shear failure at the wood-cement interface. 
The shear stress along the embedded strands under load is not homogenous and reaches a maximum at the point where the strands enter the cement matrix. The shear stress at the wood-cement interface is not linear and depends on the embedment depth as well as the elastic properties of the strand and the matrix (Lawrence 1972). Laws (1982) investigated fibres which were embedded in a matrix. For his study he assumed that the embedded end of the strand carries no load at all. In our case mechanical interlocking between cement and wood at the end of the strands can be assumed. Due to the small area of the butt end in comparison to both faces of the strands the contribution of the butt end is thought to be marginal. Taking this into account, debonding of the strand will start near the surface of the matrix where shear stress reaches a maximum. Due to the nonuniform debonding near the surface the contact area of the strand and the matrix is reduced and thereby the effective interface. Considering this fact the measured or calculated bonding strength is an underestimate of the bond as formerly assumed contact area is decreasing due to debonding (Laws 1982). A theoretical approach to avoid this error was developed by Lawrence (1972) and extended by Laws (1982). Accepting the simplifying approach the calculated shear strength gained from the pull-out tests was used to characterize the compatibility between wood and cement matrix.

Due to the minimal inhibiting properties of spruce, dry strands (12\% MC) are suitable for the production of CBCs without any further treatment (Frybort et al. 2008). Comparing the computed values in Fig 3, even untreated spruce shows comparatively good bonding strength. Using $\mathrm{Na}_{2} \mathrm{SiO}_{3}$ to enhance bonding strength between wood and cement caused an average shear strength value which was 1.3 times as high as the one of untreated strands. Research done by Pehanich et al. (2004) on the influence of fibre treatment showed similar results by comparing untreated and $\mathrm{Na}_{2} \mathrm{SiO}_{3}$ treated fibres regarding to their mechanical properties (MOR, MOE) when mixed with cement. Wienhaus (1979) refers this enhancement to the sealing effect of $\mathrm{Na}_{2} \mathrm{SiO}_{3}$ whereby diffusion of sugars out of the wood into the cement paste and vice versa is inhibited. Water glass is also known to accelerate the formation of calcium silicate hydrate (CSH) gel in the system (Yue et al. 2000), which is in large part, besides calcium carbonate, responsible for the strength properties of cement (Hermawan et al. 2001). 
Although $\mathrm{Na}_{2} \mathrm{SiO}_{3}$ itself has no accelerating effects on hydration, it is often mentioned besides others substances, as an accelerator (Wei et al. 2002).

As there is no silica available in spruce, introduction of silica into or at least onto the wooden substance is a common method to improve strength of the cement matrix and additionally bonding quality between wood and matrix. The presence of sodium, in this case sodium silicate, promotes the formation of ettringite needles (Prince et al. 2003). By the presence of ettringite needles bonding between the wood and the matrix is improved (Coatanlem et al. 2006). Due to the alkaline conditions of the cement water slurry acidic functional groups of the lignocellulosic material ionize and cations are adsorbed. By lowering the concentration of essential cations, especially of calcium, these adsorption sites disturb the complex set of reactions of cement (Pereira et al. 2003; 2005). Studies investigating the bond strength between wood strands and cement matrix are scarcely described in the literature. Also studies investigating embrittlement at the wood-cement interface due to accelerating effects are barely present in the literature. However, further research could be useful to clearly determine how the $\mathrm{Na}_{2} \mathrm{SiO}_{3}$ treatment is enhancing bond quality.

Setting accelerators are widely-used as the application is easy to accomplish, pressing and clamping time are reduced (Simatupang et al. 1990) and additionally bond quality between wood and cement is enhanced and thereby the mechanical properties of CBCs are improved.

Several substances are suitable to accelerate cement setting, e.g., $\mathrm{MgCl}_{2}, \mathrm{CaCl}_{2}$ and $\mathrm{NH}_{4} \mathrm{Cl}$, but because of the corrosive action of chlorous substances, the application of these boards is limited, hence the use of $\mathrm{Na}_{2} \mathrm{SiO}_{3}$ (Schubert et al. 1990a) or non-chlorous accelerators is preferable. The results of the accelerated samples are most likely explained by the reduced setting time, which prevents extractives to be washed out of the wood (Bietz and Uschmann 1984; Simatupang et al. 1990). But also the $\mathrm{pH}$-value has big influence on cement setting. The use of less alkali cement, or the addition of acidic substances, reduces the alkali degradation of hemicelluloses which is called peeling reaction. These degradation products, especially saccharinic acids, which arise from monomer and oligomer sugars, as well as polysaccharides (cellulose, hemicelluloses), have similar inhibitory effects on hydration like water soluble monosaccharides (Wienhaus 1979; Schubert et al. 1990b, a) whereas degradation products, e.g., saccharinic 
acids, are much more effective in inhibiting hydration of cement (Govin et al. 2005). Concerning this case Wienhaus (1979) has mentioned the impregnation of wood particles with acidic-hydrolysing salts $\left(\mathrm{CaCl}_{2}, \mathrm{MgCl}_{2}, \mathrm{Al}_{2}\left(\mathrm{SO}_{4}\right)_{3}, \mathrm{FeSO}_{4}\right)$. These salts delay the formation of an alkali milieu around wood particles, thus promoting hydration by suppressing the development of saccharinic acids.

During preparation of the accelerated samples, a liquidation of the cement water slurry could be observed. This lower viscosity could possibly have lead to a better contact between wood and cement and furthermore to an improved impregnation of the strands. Also Eusebio et al. (2000) relate this improvement to a better fibre to fibre contact when $\mathrm{CaCl}_{2}$ was used as an accelerator. A negative side effect of using setting accelerators, which was noticed by Hermawan et al. (2002), is a decrease in dimensional stability of CBCs.A quite important result of this study is the fact that wet embedded strands ( $90 \%$ MC) showed more or less the same pull-out strength like the dry strands which were embedded in cement where accelerator was added. This shows that additives are not stringently needed for spruce to enhance bonding strength between wood and cement matrix. A beneficial side effect of this elevated MC is that simultaneously some extraction is taking place when strands are stored in water. Nevertheless, to achieve this secondary goal the strands have to be extracted for more than 10 minutes like it was done for this study. Own unpublished research showed that pull-out strength is improved by hot water extraction at $60^{\circ} \mathrm{C}$ for $24 \mathrm{~h}$. But also after $6 \mathrm{~h}$ a slight increase in pull-out strength was observed.

This high bonding strength could be explained by an undisturbed cement setting. This was also observed by Dewitz et al. (1984) when they measured mass transport of minerals into sapwood of pine. By using dry wood, substances which are essential for setting are withdrawn from the cement. Wood is indeed mineralised but this is neither contributing to the strength of the matrix nor to the development of bonding strength between matrix and wood. By contrast if wet wood ( $>90 \%$ MC) was used transport of minerals was delayed for a couple of hours and minimized in intensity. Tamba et al. (2001) relate this effect to the hydrophilic nature of wood, which affects the water cement ratio and thereby limiting the water available for hydration.

The highest bonding strength could be achieved with wet strands which were embedded in cement with added accelerator. This could be related to faster setting 
times (Bietz and Uschmann 1984; Simatupang et al. 1990), as mentioned before and additionally to the reduced transport of minerals when wet wood is used (Dewitz et al. 1984).

During pull-out testing embrittlement of the strands could be observed on some of the samples, which manifested in brittle failure near the embedment zone. Embrittlement is known to be caused by the alkaline environment provided by the cement (Youngquist 1999) but could partly also be caused by the mineralization of the wood surface. Cziesielski (1975) has already reported that wood surfaces which are in direct contact to cement experience mineralization. Concerning this fact further studies have to be done to clearly determine the influence of embrittlement on the strength of wood particles.

Most of the samples showed discoloration on the wood surface. This can be attributed to the reaction of alkali chemicals of cement with wood. It is assumed that discoloration is mostly caused by water soluble phenolic components but also by lignin (Hon and Shiraishi 2001). Especially the untreated samples with added accelerator, as well as the $\mathrm{NaOH}$ treated samples showed increased discoloration up to $30 \mathrm{~mm}$ above the embedment zone while the wet ones, also the wet ones with added accelerator, did not show an apparent discoloration. Due to the elevated moisture content of the strands additional water absorption could not take place. Thus no alkali substances could penetrate into the strands and therefore no discolouration occurred.

The results of the thick samples $(800 \mu \mathrm{m})$ showed that geometry of the strands, in this case thickness, has great influence on the development of bond strength (Badejo 1988). That is why no significant difference between the untreated and even the $\mathrm{Na}_{2} \mathrm{SiO}_{3}$ treated strands could be observed (Fig. 4). It can be assumed that bonding strength at the wood-cement interface was significantly reduced by shrinkage of the strands during the time the cement cured. Due to shrinkage of the strands cross tension and shear forces are induced which cause de-bonding at the wood-cement interface.

$\mathrm{NaOH}$ treatment does just barely enhance bonding strength although it is described as being able to enhance compatibility by removing inhibitory substances (Moslemi et al. 1983). However, this may just be the case for highly incompatible species like larch but not for spruce, as it is described as a low inhibitory species (Schubert et al. 1990a), thus the difference is not that 
conspicuous. Anyway, treatment of particles with diluted $\mathrm{NaOH}(0.5 \%, 2 \mathrm{~h})$ is cited as being able to reduce thickness swelling of CBCs (Kavvouras 1987), which could be confirmed by our own research.

The data obtained in this study suggests that using wet spruce (MC 90\%) as reinforcement enhances bonding strength compared to dry wood (12\%). On the other hand, addition of $2 \% \mathrm{NH}_{4} \mathrm{Cl}$ as accelerator will generate even better results for untreated wet spruce.

\section{Conclusion}

As spruce causes marginal compatibility problems, there is no necessary need for extraction. Nevertheless, a slight increase in bonding strength could be measured when using hot water or diluted $\mathrm{NaOH}$ extraction which results from removal of several polysaccharides. However, a more effective and economic method to enhance mechanical properties is by using wooden material with an elevated MC. At $20 \%$ a slight enhancement took place, while at around $90 \% \mathrm{MC}$ the pull-out strength nearly doubled, compared to $12 \% \mathrm{MC}$.

The application of $\mathrm{Na}_{2} \mathrm{SiO}_{3}$ onto the wood particles is beneficial and therefore a conventional method for enhancing mechanical properties of CBCs. Compared to strands embedded in accelerated cement this method is more sophisticated to accomplish as strands have to be treated prior to mixing with cement.

The addition of accelerators, in this case $\mathrm{NH}_{4} \mathrm{Cl}$, enhances mechanical properties, though by reducing setting time at the same time. Using accelerators may be much more uncomplicated for the industrial process, as the additive is just admixed to the neat cement powder. Both untreated (12\%) and wet ( 90\%) strands achieved superior bonding strength, whereas wet strands produced highest bonding strength.

Thin, but also long particles have to be preferred when mechanical properties, as well as low thickness swelling are the desired key properties for CBCs. 
Alberto MM, Mougel E, Zoulalian A (2000) Compatibility of some tropical hardwood species with Portland cement using isothermal calorimetry. Forest Prod J 50:83-88

Badejo SOJ (1988) Effect of flake geometry on properties of cement-bonded particleboard from mixed tropical hardwoods. Wood Sci Technol 22:357-370

Banholzer B, Brameshuber W, Geus J, Jung W (2004) Bestimmung eines Verbundgesetzes auf Basis von Einzelfaser-Pull-Out-Versuchen. Bautechnik 81(10):806-812

Bietz H, Uschmann W (1984) Zum Verfestigungsverhalten von Holz-Zement-Verbunden beim Einsatz von Holzresten. Holztechnologie 25(3):116-118

Brandstetr J, Polcer J, Krátký J, Holesinsky R, Havlica J (2001) Possibilities of the use of isoperibolic calorimetry for assessing the hydration behaviour of cementitious systems. Cement Concrete Res 31:941-947

Coatanlem P, Jauberthie R, Rendell F (2006) Lightweight wood chipping concrete durability. Construction and Building Materials 20:776-781

Cziesielski E (1975) Beton mit Fasern aus Holz. Holz Roh Werkst 33(303-307

Dewitz K, Kuschy B, Otto T (1984) Stofftransporte bei der Abbindung zementgebundener Holzwerkstoffe. Holztechnologie 3:151-154

Eusebio DA (2003). Cement bonded board: Today's Alternative. Technical Forum in celebration of the PCIERD $21^{\text {st }}$ anniversary Pasig City, Philippine,

Eusebio DA, Soriano FP, Cabangon RJ, Evans PD (2000). Manufacture of low-cost wood-cement composites in the Philippines using plantation-grown Australian species: I. Eucalyptus. WoodCement Composites in the Asia-Pacific Region, Canberra, Australia,

Evans AG, Zok FW, Davis J (1991) The role of interfaces in fiber-reinforced brittle matrix composites. Composite Science and Technology 42:3-24

Frybort S, Mauritz R, Teischinger A, Müller U (2008) Cement bonded composites - A mechanical review. Bioresources 3:602-626

Geimer RL, Souza MR, Moslemi AA (1996) Low-density cement-bonded wood composites made conventionally and with carbon dioxide injection. Drvna Industrija 47(2): 55-62

Govin A, Peschard A, Fredon E, Guyonnet R (2005) New insights into wood and cement interaction. Holzforschung 59:330-335

Hermawan D, Hata T, Kawai S, Nagadomi W, Kuroki Y (2002) Manufacturing oil palm fronds cement-bonded board cured by gaseous or supercritical carbon dioxide. J Wood Sci 48:20-24

Hermawan D, Hata T, Umuemura K, Kawai S, Nagadomi W, Kuroki Y (2001) Rapid production of high-strength cement-bonded particleboard using gaseous or supercritical carbon dioxide. J Wood Sci 47:294-300

Hon DNS, Shiraishi N (2001). Wood and Cellulosic Chemistry. New York - Basel, Marcel Dekker, Inc.

Issa MA, Shafiq AB, Hammad AM(1996) Crack arrest in mortar matrix reinforced with unidirectionally aligned fibers. Cement and Concrete Research 26(8):1245-1256

Jorge FC, Pereira C, Ferreira JMF (2004) Wood-cement composites: a review. Holz Roh Werkst $62: 370-377$

Karade SR, Irle M, Maher K (2003) Assessment of wood-cement compatibility: A new approach. Holzforschung 57:672-680

Kavvouras PK (1987) Suitability of Quercus conferta wood for the manufacture of cement-bonded flakeboards. Holzforschung 41:159-163

Lange DA, Ouyang C, Shah SP (1996) Behavior of cement based matrices reinforced by randomly dispersed microfibers. Advanced Cement Based Materials 3(1):20-30 
Lawrence P (1972) Some theoretical considerations of fibre pull-out from an elastic matrix. J Mater Sci 7:1-6

Laws V (1982) Micromechanical aspects of the fibre-cement bond. Composites 113:145-151

Lee AWC, Hong Z (1986) Compressive strength of cylindrical samples as an indicator of woodcement compatibility. Forest Prod J 36:87-90

Moslemi AA, Garcia JF, Hofstrand AD (1983) Effect of various treatments and additives on wood-Portland cement-water systems. Wood Fibre Sci 15:164-176

Pehanich JL, Blankenhorn PR, Silsbee MR (2004) Wood fiber surface treatment level effects on selected mechanical properties of wood fiber-cement composites. Cement Concrete Res 34:59-65

Pereira C, Jorge FC, Ferreira JMF (2005) Adsorption of Cations from a Cement Suspension onto Lignocellulosic Substrates and its Influence on Cement Setting. J Wood Chem Technol 25:231244

Pereira C, Jorge FC, Irle MA, Ferreira JM (2003) Extractive contents of two woods and cork of Portuguese origin and the interaction of these substrates with cement suspensions. Forest Prod $\mathbf{J}$ $53: 34-43$

Prince W, Espagne M, Aitcin PC (2003) Ettringite formation: A crucial step in cement superplasticizer compatibility. Cement Concrete Res 33:635-641

Schubert B, Wienhaus O, Bloßfeld O (1990a) Untersuchungen zum System Holz-Zement. Einfluss unterschiedlicher Holzarten auf das Abbindeverhalten von Holz-Zement-Mischungen und Möglichkeiten zur Modifizierung des Systems. Holz Roh Werkst 48(11):423-428

Schubert B, Wienhaus O, Bloßfeld O (1990b) Untersuchungen zum System Holz-Zement. Einfluß unterschiedlicher Zementarten auf das Abbindeverhalten von Holz-Zement-Mischungen. Holz Roh- Werkst 48(5):185-189

Simatupang MH, Seddig N, Habighorst C, Geimer R (1990). Technologies for rapid production of mineral-bonded wood composite boards. Proceedings of the $2^{\text {nd }}$ International Inorganic Bonded Wood and Fiber Composite Materials Conference, Madison, Wisconsin, USA, Forest Products Research Society

Tamba S, Jauberthie R, Lanos C, Rendell F (2001) Lightweight wood fibre concrete. Concr Sci Eng 3:53-57

Wei YM, Fujii T, Hiramatsu Y, Miyatake A, Yoshinaga S, Fujii T, Tomita B (2004) A preliminary investigation on microstructural characteristics of interfacial zone between cement and exploded wood fiber strand by using SEM-EDS. J Wood Sci 50:327-336

Wei YM, Tomita B, Hiramatsu Y, Miyatake A, Fujii, T, Fujii T, Yoshinaga S (2003) Hydration behavior and compressive strength of cement mixed with exploded wood fiber strand obtained by the water-vapor explosion process. J Wood Sci 49:317-326

Wei YM, Tomita B, Hiramatsu Y, Miyatake A, Fujii T (2002) Study of hydration behaviors of wood-cement mixtures: compatibility of cement mixed with wood fiber strand obtained by the water-vapor explosion process. J Wood Sci 48:365-373

Wei YM, Zhou YG, Tomita B (2000a) Hydration behavior of wood cement-based composite I: evaluation of wood species effects on compatibility and strength with ordinary Portland cement. J Wood Sci 46:296-302

Wei YM, Zhou YG, Tomia B (2000b) Study of hydration behavior of wood cement-based composite. II: effect of chemical additives on the hydration characteristics and strengths of woodcement composites. J Wood Sci 46:444-451

Wienhaus O (1979) Werkstoffe aus Holz und Zement. Holztechnologie 20(4):207-215

Wolfe RW, Gjinolli A (1996). Cement-Bonded Wood Composites as an Engineering Material. The Use of Recycled Wood and Paper in Building Applications, Madison, Wisconsin, Forest Products Society

Youngquist JA (1999). Wood-based composites and panel products. Wood handbook: wood as an engineering material. Madison, Wisconsin, USA, U.S. Dept. of Agriculture, Forest Service, Forest Products Laboratory. 
Yue YL, Li GZ, Xu XS, Zhao ZJ (2000) Properties and microstructures of plant-fiber-reinforced cement-based composites. Cement Concrete Res 30:1983-1986 
Table 1 Description of the different treatments of the specimens.

Tabelle 1 Beschreibung der unterschiedlichen Behandlungen der Probekörper.

\begin{tabular}{|l|l|}
\hline Name & Treatment \\
\hline none & conditioned $12 \% 1$ \\
\hline wet & 10 min in $\mathrm{H}_{2} \mathrm{O}(\sim 92 \%)^{2}$ \\
\hline $\begin{array}{l}\mathrm{NaOH} \text { (sodium } \\
\text { hydroxide } \\
\text { solution) }\end{array}$ & $1 \%$ dilution $-1 \frac{1}{2} \mathrm{~h}$ \\
\hline $\begin{array}{l}\mathrm{Na}_{2} \mathrm{SiO} \\
\text { silicate solution) }\end{array}$ & $2 \%$ dilution $-1 \frac{1}{2} \mathrm{~h}$ \\
\hline none + accelerator & conditioned $12 \% 1-2 \%$ of $\mathrm{NH}_{4} \mathrm{Cl}$ based on cement weight \\
\hline wet + accelerator & $\begin{array}{l}10 \text { min in } \mathrm{H}_{2} \mathrm{O}(\sim 92 \%)^{2}-2 \% \text { of } \mathrm{NH}_{4} \mathrm{Cl} \text { based on cement } \\
\text { weight }\end{array}$ \\
\hline
\end{tabular}

The strands were stored in a climate room $\left(20^{\circ} \mathrm{C}, 65 \% \mathrm{RH}\right)$ for one week.

2 The strands, which were stored in the climate room, were dipped in water at room temperature for $10 \mathrm{~min}$. 
Table 2 Results of the pull out test, $\mathrm{n}=$ number of samples, $\tau=$ pull-out or shear strength, $\mathrm{s}=$ standard deviation.

Tabelle 2 Ergebnisse des Auszugstests, $\mathrm{n}=$ Probenanzahl, $\tau$ = Auszugs- bzw. Scherfestigkeit, $\mathrm{s}=$ Standardabweichung.

\begin{tabular}{|c|c|c|c|c|}
\hline \multirow[b]{2}{*}{ Treatment } & \multirow{2}{*}{$\begin{array}{c}\text { planned } \\
\text { embedment } \\
\text { depth (mm) }\end{array}$} & \multirow[b]{2}{*}{$\mathrm{n}$} & \multicolumn{2}{|c|}{ pull-out strength $\left(\mathrm{N} / \mathrm{mm}^{2}\right)$} \\
\hline & & & $\tau$ & $\mathrm{s}$ \\
\hline $12 \%$ & 15 & 9 & 0.29 & 0.066 \\
\hline $20 \%$ & 15 & 11 & 0.34 & 0.126 \\
\hline $\mathrm{NaOH}$ & 15 & 11 & 0.35 & 0.086 \\
\hline wet & 15 & 10 & 0.44 & 0.166 \\
\hline $12 \%$ & 10 & 14 & 0.36 & 0.0718 \\
\hline $\mathrm{Na}_{2} \mathrm{SiO}_{3}$ & 10 & 14 & 0.47 & 0.079 \\
\hline $12 \%+\mathrm{NH}_{4} \mathrm{Cl}$ & 10 & 13 & 0.57 & 0.096 \\
\hline wet & 10 & 11 & 0.59 & 0.103 \\
\hline wet $+\mathrm{NH}_{4} \mathrm{Cl}$ & 10 & 8 & 0.73 & 0.076 \\
\hline
\end{tabular}




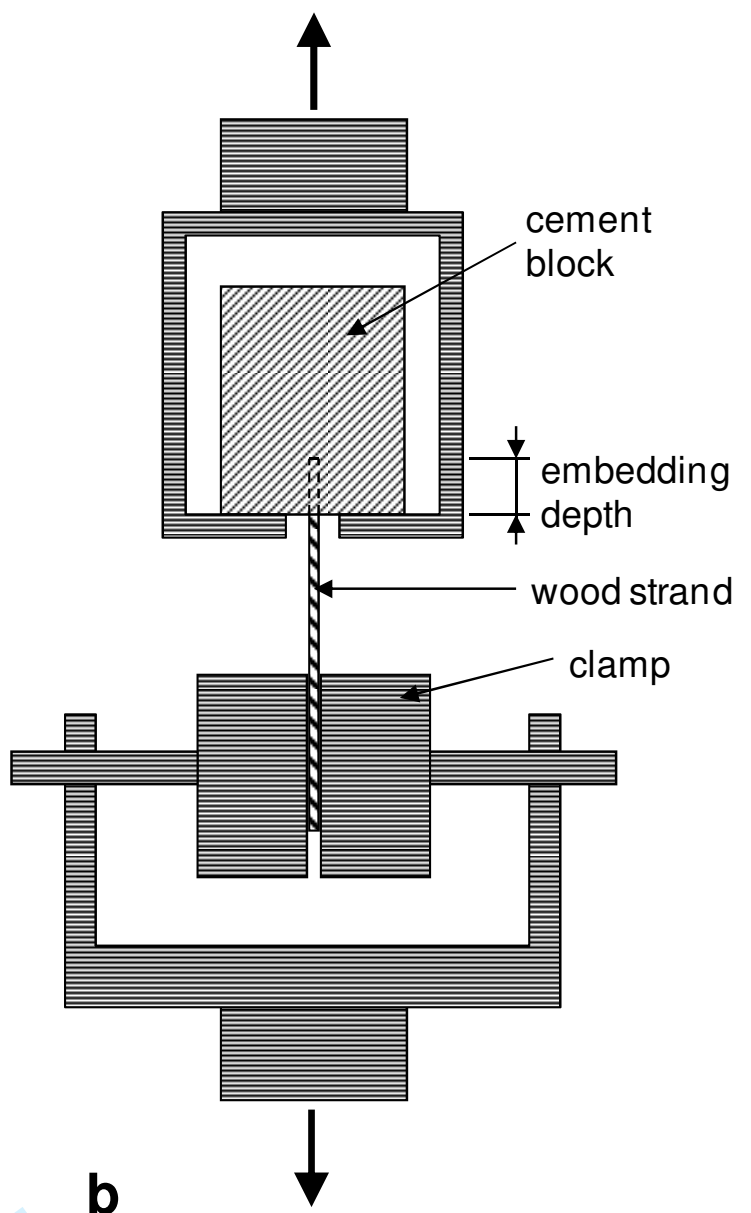

Fig. 1 a Schematic illustration of strand preparation, dimensions in mm. b Clamped specimen during pullout test.

Abb. 1 a Schematische Darstellung der Strand-Herstellung, Abmessungen in mm. b eingespannte Probe im Auszugstest. 


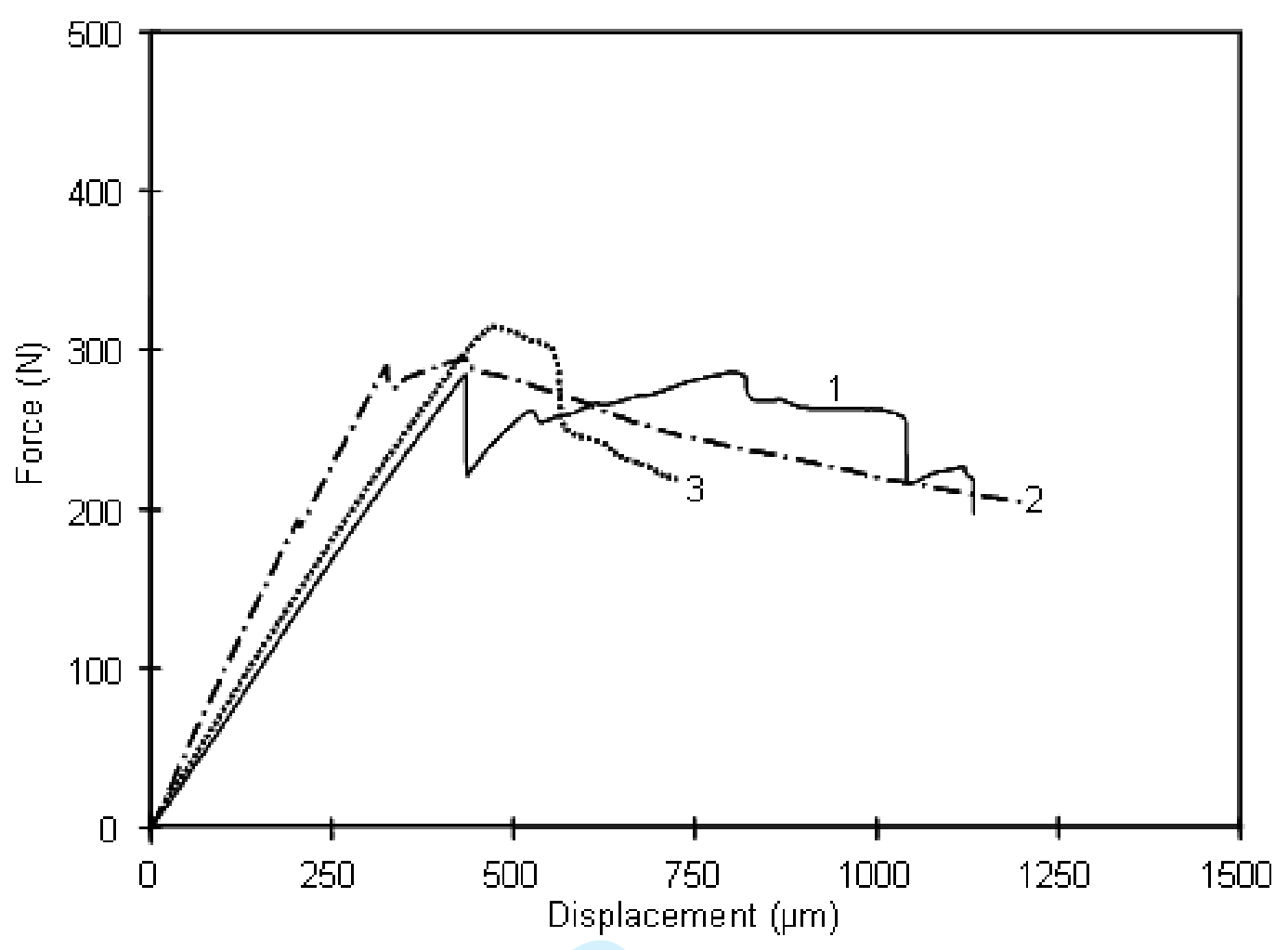

Fig. 2 Examples of different load displacement curves of the pull-out test: 1 saw tooth pattern, 2 debonding followed by a slight load increase and subsequent nearly linear load decrease, 3 debonding followed by a force decline.

Abb. 2 Beispiele für verschiedene Formen des Kraft-Weg-Diagramms der Auszugsprüfung: 1 Sägezahnmuster, langsamer Abfall des Auszugswiderstandes, 2 Ablösung gefolgt von einem kurzen Anstieg und anschließendem fast linearem Kraftabfall, 3 Ablösung gefolgt von einem Kraftabfall. 


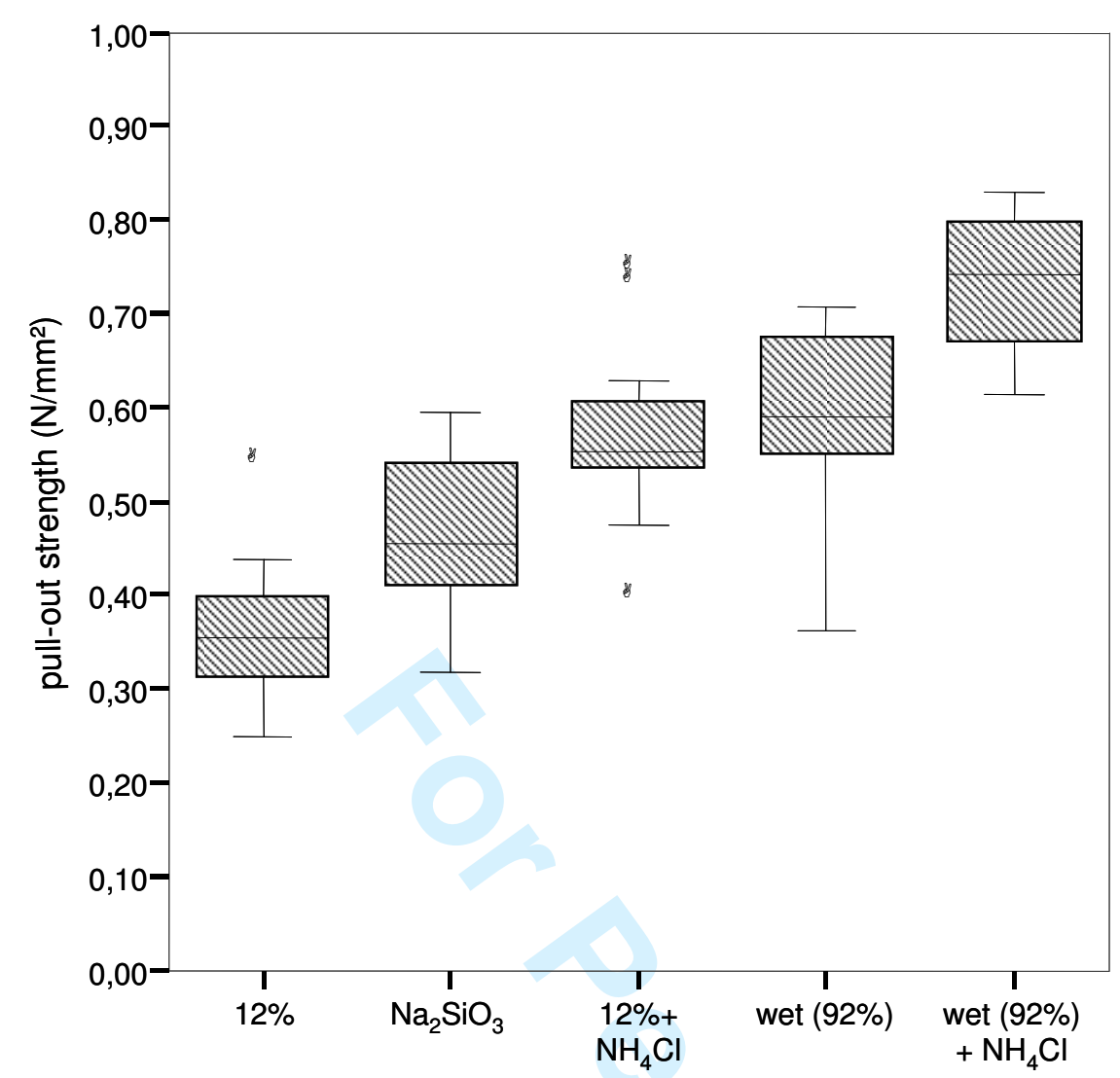

Fig. 3 Pull-out strength plotted over the different strand treatments (none, wet and sodium silicate solution), with or without added accelerator $\left(\mathrm{NH}_{4} \mathrm{Cl} 2 \%\right.$ based on cement weight), strand thickness $400 \mu \mathrm{m}$, embedment depth $10 \mathrm{~mm}$.

Abb. 3 Auszugsfestigkeit gegenüber den unterschiedlichen Behandlungen der Strands, unbehandelt (none), feucht (wet) und Wasserglas $\left(\mathrm{Na}_{2} \mathrm{SiO}_{3}\right)$, mit und ohne Zugabe eines Beschleunigers $\left(\mathrm{NH}_{4} \mathrm{Cl} 2 \%\right.$ bezogen auf Zementgewicht), Stranddicke $400 \mu \mathrm{m}$, Einbettungstiefe $10 \mathrm{~mm}$. 


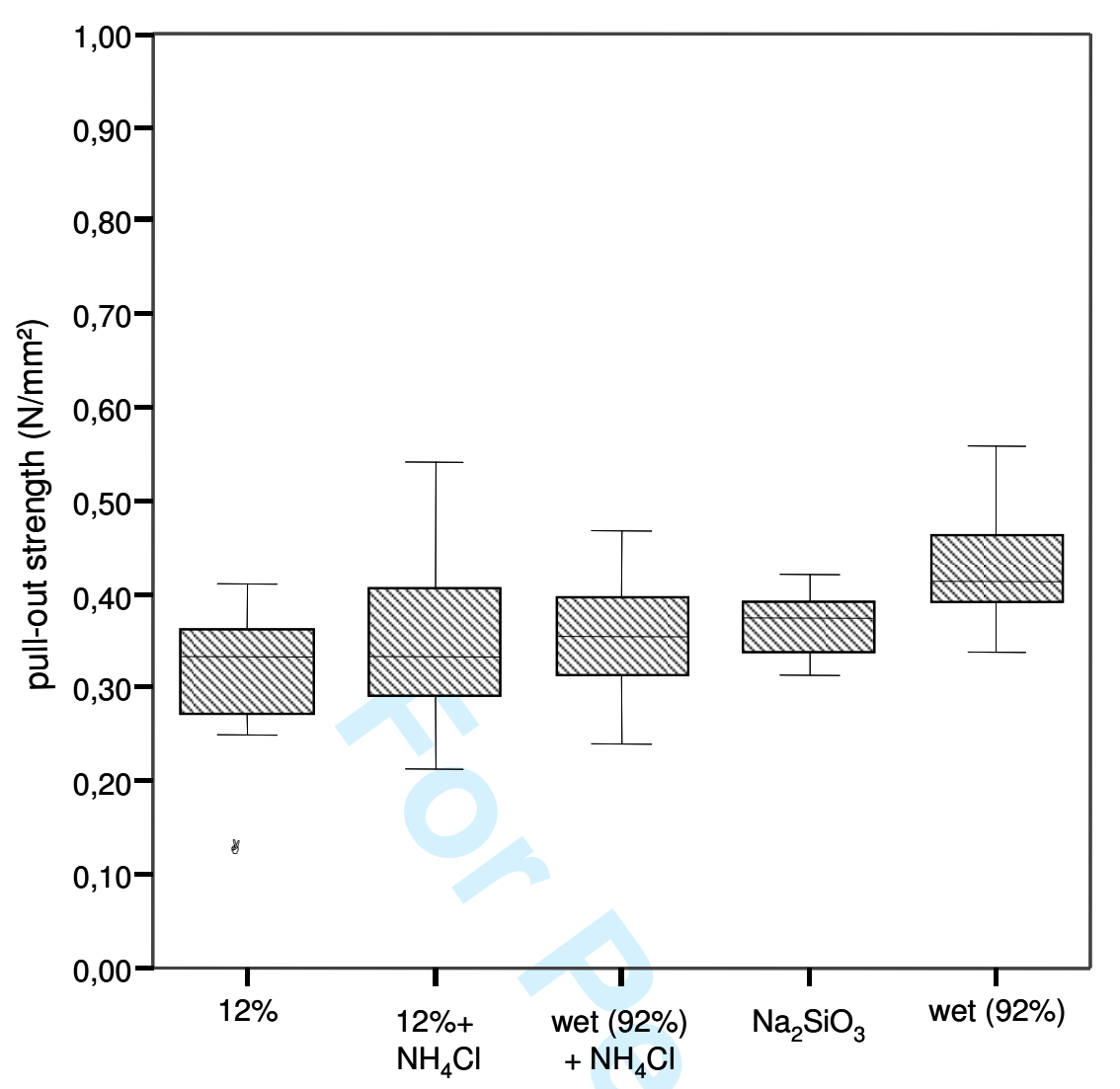

Fig. 4 Pull-out strength of a previous study plotted over the different strand treatments, no treatment $(12 \%)$, no treatment with added accelerator, wet with added accelerator, sodium silicate solution, and wet, strand thickness $800 \mu \mathrm{m}$, embedment depth $15 \mathrm{~mm}$.

Abb. 4 Auszugsfestigkeit gegenüber den unterschiedlichen Behandlungen der Strands, unbehandelt (12\%), unbehandelt mit Zugabe eines Beschleunigers $\left(12 \%+\mathrm{NH}_{4} \mathrm{Cl}\right.$,), feucht mit Zugabe eines Beschleunigers (wet\% $+\mathrm{NH}_{4} \mathrm{Cl}$,), Wasserglas $\left(\mathrm{Na}_{2} \mathrm{SiO}_{3}\right)$ und nass $(92 \%)$, Stranddicke $800 \mu \mathrm{m}$, Einbettungstiefe $15 \mathrm{~mm}$. 